\title{
Isolation and characterization of hydrocarbon-degrading fungi from Ogbe- Ijoh oil creek, Warri, Delta State, Nigeria
}

\author{
Faith Iguodala AKINNIBOSUN* and Abigail ASHEGBARE \\ Department of Microbiology, Faculty of Life Sciences, University of Benin, P. M. B 1154, Benin City, Edo State, \\ Nigeria
}

\begin{abstract}
This study was aimed at isolating and characterizing hydrocarbon-degrading fungi from hydrocarboncontaminated soil in Ogbe-Ijoh oil creek in Warri, Delta State, Nigeria. Isolation and characterization were carried out using standard methods. Biodegradation assay was carried out over 25 days and monitored using the following parameters; $\mathrm{pH}$, total organic carbon, and total hydrocarbon content. The fungi isolated were: Penicillium sp., Aspergillus niger and Fusarium sp., and these were used for the biodegradation study. Physico-chemical analysis of the crude oil contaminated soil during degradation showed that there was significant decrease in $\mathrm{pH}$ during degradation from day 10 $25(p \geq 0.05)$. This showed the ability of the fungal isolates to utilize crude oil as carbon source, producing acid during its metabolism. The highest $\mathrm{pH}$ value during degradation by the fungal isolates was recorded in Fusarium sp. and the lowest was recorded in Aspergillus sp. The fungal isolates were able to reduce the total carbon and hydrocarbon content during degradation. This was probably due to the utilization of the nutrients in the soil sample as energy source. The results from this study indicate the potential of the isolated fungi for hydrocarbon bioremediation activity.
\end{abstract}

Keywords: bioremediation, degradation potential, hydrocarbon-utilizing fungi, mycoflora, pollution.

\section{Introduction}

Lately, many microbial ecologists have detected a range of microbial strains which are successful at breaking down / degrading hydrocarbons in geological ecosystems. Several of these microbial confederations have been sequestered from severely polluted coastline. These microbes were isolated on their capacity to absorb and breakdown various carbon sources viz aliphatic and aromatic complex and their chlorinated derivatives. The microbes were obtained formerly by enrichment culture technique, where the highest precise proliferation rate or the ultimate cell density was used as the designated benchmark.

Fossil hydrocarbons can be broken down by microbes such as bacteria, fungi, yeast and microalgae [1]. The impelling cause for petroleum biodegradation is the proficiency of microorganisms to make use of hydrocarbons to meet their cell development and energy requirements. A considerable volume of studies account that low molecular weight alkanes are broken down most quickly. Mixed cultures perform more wide-range biodegradation of petroleum than pure cultures [2 - 5]. In many biomes, there is previously an ample aboriginal microbial population competent of massive biodegradation, granted that the environmental situations are promising for oil-degrading metabolic activity [6 - 8]. There are numerous merits counting on aboriginal microbes preferably than introduced microbes to break down hydrocarbons. Essentially, natural microbial populace has settled across many years. These microorganisms are tailored for persistence and propagation in that environment. Moreover, the capacity to degrade hydrocarbons is dispersed among a varied microbial population. This population exists in the biological ecosystem and either freely or in combination metabolizes a range of hydrocarbons. Repeatedly, when microorganisms are abundant in the polluted environment, microbial amendment is not essential. The availability of nutrients, notably of nitrogen and phosphorus appears to be the very constraining factor having been established that these nutrients augment growth of microorganisms, leading to additional prompt degeneration of contaminants [9]. Expected standards for a mixed microbial population in the soil are $\mathrm{C}: \mathrm{N}, 10: 1$ and $\mathrm{C}: \mathrm{P}, 100: 1$. Phosphorous and nitrogen can be made available with common inorganic fertilizers in the $\mathrm{N}: \mathrm{P}$ ratio at $16: 1$ when the ideal nitrogen fertilization for a sandy medium is lower than $100 \mathrm{mg} \mathrm{N} \mathrm{kg}$ dry soil mates [10].

Microbes are armed with metabolic mechanism to use petroleum products is their source of carbon and energy. The metabolic route that hydrocarbon-degrading heterotrophs employ can either be aerobic (i.e. they make use of oxygen as the basic electron acceptor) or anaerobic (i.e. they make use of a substitute electron acceptor like nitrate or sulfate). Aerobic degradation frequently proceeds more quickly and is arguably to be more efficient than anaerobic degradation. An important reason is that aerobic reactions demands less free energy to kick off and produce more energy for every reaction. Fungal genera, specifically, Amorphoteca, Graphium, Talaromyces, and Neosartorya were isolated from petroleum-polluted soil and confirmed to be the probable organisms for hydrocarbon degradation. Singh also stated that an assemblage of terrestrial fungi, specifically, Aspergillus, Cephalosporium, and Pencillium were also

\footnotetext{
* Corresponding author. E-mail address: faith.akinnibosun@uniben.edu (Faith Iguodala Akinnibosun)
} 
established to be the likely degraders of crude oil hydrocarbons [11].

This study aimed at isolating, identifying and screening for biodegradation abilities of hydrocarbondegrading fungi from crude oil-contaminated soil collected from Ogbe-Ijoh oil creek in Warri, Delta State.

\section{Experimental}

\subsection{Materials}

The high purity reagents were obtained from SigmaAldrich Inc., Missouri, USA, being used as received without further purification.

\subsection{Study area}

In consensus to environmental specialists from the UK, the USA and Nigeria, the Niger Delta is ranked as the most oil-impacted environment and contaminated / polluted area in the world $[12,13]$. Warri is a city in Delta state, Nigeria, located at N $05^{\circ} 03^{\prime} 100^{\prime \prime}$, E $005^{\circ} 04^{\prime} 500^{\prime \prime}$. It is an oil hub in South-South Nigeria. Ogbe-Ijoh oil creek is in Warri, Delta State.

\subsection{Sample collection}

The soil for sampling was collected from surface level and kept in sterile polyethylene bag which was later taken to the laboratory for examination. The soil samples were air dried at room temperature for two days and sieved.

\subsection{Isolation and enumeration of microorganisms}

$10 \mathrm{~g}$ of the soil samples were weighed using an analytical balance and mixed with $90 \mathrm{ml}$ of sterile distilled water to form the stock suspension. $1.0 \mathrm{ml}$ of the stock suspension was transferred into a disinfected test tube containing 9.0 $\mathrm{ml}$ of sterilized distilled water. This process was repeated for other sterilized test tubes so that at the end, $1 \mathrm{ml}$ from $10^{-1}, 10^{-3}, 10^{-5}$ dilution was then plated out by pour plate method on Potato Dextrose Agar. The Potato Dextrose Agar plates were amended with streptomycin to prevent bacterial growth and incubated at room temperature $28 \pm$ $2{ }^{\circ} \mathrm{C}$ for 72 hours.

\subsection{Isolation and characterization of hydrocarbon- degrading fungi}

Aliquot of the appropriate dilution was plated in Mineral Salt Agar (MSA). The Mineral Salt Agar was amended with streptomycin to thwart the growth of bacteria, in order to isolate hydrocarbon-degrading fungi. Plates were incubated at room temperature $\left(28 \pm 2{ }^{\circ} \mathrm{C}\right)$ for 72 hours.

\subsection{Characterization of fungal isolates}

The fungal species were identified and characterized based on their morphological characteristics and microscopic analysis through slide culture technique with simple modification [14] and by employing taxonomic guides [15].

\subsection{Determination of hydrocarbon utilization}

The growth potentials of the fungal isolates were performed using a modified method of Mandri and Lin [16]. A single colony of each isolate was inoculated into $10 \mathrm{ml}$ of Bushnell-Haas and incubated on a shaker at 130 $\mathrm{rpm}$ at room temperature for 7 days with $1 \%(\mathrm{v} / \mathrm{v})$ filter sterilized crude oil as only carbon in shaker. After 7 days, turbidity was assessed spectrophotometrically and recorded as high (+++), moderate $(++)$ or low (+) and no growth (-) depending on the level of turbidity. The fungal isolates with the highest visualized turbidity were selected for the degradation tests.

\subsection{Assessment of growth rate of degradation}

Growth of the isolates during degradation was monitored by spectrophotometric measurement of absorbance at $560 \mathrm{~nm}$ absorbance and counting of the viable cells by plating $1 \mathrm{ml}$ of $10^{-4}$ serial dilution of Bushnell-Haas medium Potato Dextrose Agar for fungi at an interval of 24 hours for 5 days.

\subsection{Data statistical analysis}

The experimental procedure was replicated three times. Data obtained were analyzed using mean, standard deviation (SD) and analysis of variance (ANOVA) to determine differences and Duncan's multiple range tests to separate the means. These analyses were carried out using Statistical Package for Social Sciences (SPSS) Package Version [17].

\subsection{Physico-chemical analysis}

Sample $\mathrm{pH}$, total organic carbon (TOC) and total petroleum hydrocarbons (TPH) were determined by electrochemical method, wet oxidation method and gravimetric method respectively as described by Iwegbue et al. [18] and confirmed by APHA [19].

\section{Results and discussion}

This study investigated the capability of fungi to break down crude oil-contaminated soil under a time-course experiment as well as isolating and characterizing the hydrocarbon degrading-fungi from the crude oilcontaminated soil. Microorganisms that can survive and grow in such contaminated sites could be used as biocleaning tools, to enhance environmental safety in such contaminated site. Any compound that can be degraded by microorganisms almost invariably serve as carbon source to them. Following utilization of the carbon source, the microorganisms sequentially attack the parent molecule. Various studies have been reported on microbial enhanced degradation of recalcitrant molecule in the environment.

Fungal species isolated included Penicillium sp., Aspergillus niger, and Fusarium sp. (Table 1). These organisms have been linked with petroleum product degradation [20] and had been isolated from crude oil contaminated soil [21]. Previous study on isolation of fungi done by Enabulele and Obayagbona [22]; Obire et al. [23]; Ekhaise and Nkwelle [24]; Adeyemo et al. [25], showed that mycoflora isolated are in accordance with present study. Investigation by Wemedo et al. [26] also documented that genera of namely Penicillium sp., Aspergillus sp. and Rhizopus sp. are linked with kerosene-polluted soil. It was also reported by Oboh et al. [27] that all of these isolates were capable of growing on crude petroleum as the only carbon and energy source when tested for hydrocarbon utilization. Aspergillus and Penicillium sp. have recurrently been sequestered from marine and terrestrial environments. Earlier works also documented the occurrence of these fungi in domestic effluent, animal dung, poultry droppings and abattoir 
effluent [28 - 30]. Ability of these microorganisms to propagate in crude oil contaminated soil is a reflection of their potential to utilize petroleum products as carbon sources. Crude oil composes of an assortment of paraffin, alicyclic and aromatic hydrocarbons [31].

Table 1. Cultural and microscopic characteristics of the fungal isolates

\begin{tabular}{|c|c|c|c|}
\hline Isolate & Cultural & Microscopic examination & Fungal isolates \\
\hline F1 & $\begin{array}{l}\text { Green flat colony with } \\
\text { reverse side dirty white }\end{array}$ & $\begin{array}{l}\text { Brush-like conidia, septate branching conidiophores } \\
\text { was smooth/rough walled }\end{array}$ & Penicillium sp. \\
\hline $\mathrm{F} 2$ & $\begin{array}{l}\text { Black fluffy colonies with } \\
\text { reverse side yellow }\end{array}$ & Simple septate and branched conidia in chains & Aspergillus niger \\
\hline F3 & $\begin{array}{l}\text { White and cottony } \\
\text { mycelium }\end{array}$ & $\begin{array}{l}\text { Multi-segmented canoe-like spores with branched } \\
\text { and segmented conidiophores }\end{array}$ & Fusarium sp. \\
\hline
\end{tabular}

Ability of these microorganisms to propagate in crude oil-polluted soil is a reflection of their potential to make use of petroleum products as their carbon sources. The observed capability of the fungal isolates to utilize the crude oil in the polluted soil suggests that the indigenous microorganisms have the potential to be used in bioremediation of the soil (Table 2). The exploitation of the hydrocarbons brought about increase in cell densities with an associated visual steady decline in the oil layer and utter disappearance of the oil with protracted incubation. Fungi have been found to utilize hydrocarbons and its derivatives as carbon sources which is a criterium for their multiplication. They are usually present in soil samples contaminated with hydrocarbons, with low molecular weight hydrocarbons that are bioavailable for their use [32]. Therefore, the relatively high percentage of hydrocarbon degraders recorded in the soil may be as a result of the stimulating effect of supplementary carbon source for energy and growth [33, 34].

Table 2. Utilization of crude oil by the fungal isolates

ISOLATES TURBIDITY

\begin{tabular}{llllll}
\hline & Day 0 & Day 1 & Day 2 & Day 3 & Day 4 \\
\hline Penicillium sp. & + & + & ++ & +++ & +++ \\
Aspergillus niger & + & + & ++ & ++ & +++ \\
Fusarium sp. & + & + & + & ++ & ++ \\
\hline
\end{tabular}

KEYS: + Little growth; ++ Moderate growth; +++ Heavy growth.

Biodegradation study of crude oil was observed for a period of 25 days with observation of physic-chemical parameters at 5 days interval. $\mathrm{pH}$ of the crude oil was observed to decrease from 8.86 - 7.34. This shows the capacity of the fungal isolates to make use of crude oil as carbon source, producing acid during its metabolism. The acid produced subsequently turned the solution acidic, compared to the control experiment in which the solution remained alkaline. The highest $\mathrm{pH}$ value during degradation by the fungal isolates was recorded in Fusarium sp. and the lowest was recorded in Aspergillus sp. (Figure 1). There was significant decrease in $\mathrm{pH}$ during degradation from day $10-25(p \geq 0.05)$. The reduction in $\mathrm{pH}$ during the experiment within the 25 days incubation period further established chemical changes of the hydrocarbon substrates which must have been precipitated by microbial enzymes. The degradation of hydrocarbons by the microorganisms frequently resulted in production of organic acids and additional metabolic products $[35,36]$. Thus, the acids most likely produced account for the drop in $\mathrm{pH}$ levels removing hydrocarbon pollutants from oil impacted environment. Boochan et al. [37] accounted that ideal $\mathrm{pH}$ for bioremediation is amid 6.0 and 8.9. They also opined that deviations from preliminary levels of $\mathrm{pH}$ might be as a result of the liberation of acidic and alkaline intermediates and final products in the course of biodegradation of hydrocarbons which has an effect on the $\mathrm{pH}$.

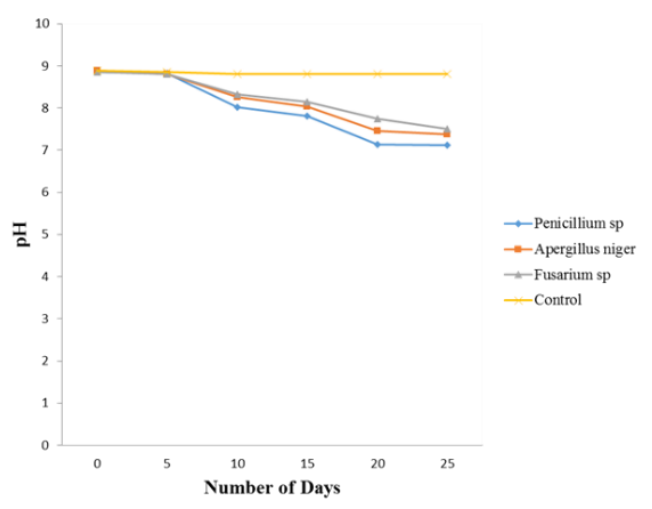

Figure 1. $\mathrm{pH}$ variation during the fungal degradation

It was observed that, there was a gradual depletion of organic carbon during the degradation process (Figure 2). This was most likely due to the consumption of the nutrients in the soil sample as energy source. This has also been reported by other researchers [38]. 


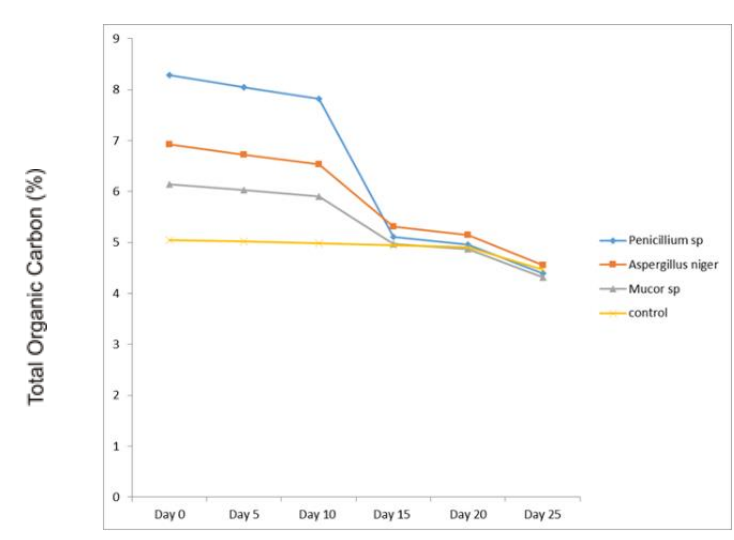

Figure 2. Total organic carbon during fungal degradation

The total hydrocarbon content was observed to drastically decrease during the biodegradation studies (Figure 3). Towards the end of the degradation process, it was observed that the degradation process was slow and minimal amount of total carbon content and total hydrocarbon content were observed, this may be as a result of the reduced amount of nutrients (nitrogen and phosphorus) in the contaminated soil, since they are both essential nutrients for effective degradation. This is in consonance with the result of Anyasi and Atagana [39], who documented that degradation of crude oil was highest in the initial few days of their research, and gradually declined as time progressed, notwithstanding of the amount of microorganisms present. For effective and successful bioremediation process, the test matrix or experiment should be sufficiently biostimulated (addition of nutrient) or bioaugumented (addition of organisms) [40].

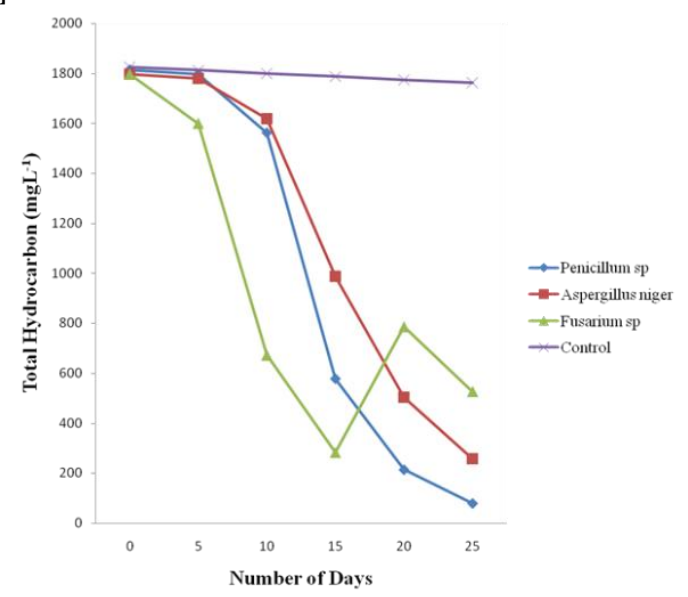

Figure 3. Total hydrocarbon during fungal degradation

\section{Conclusion}

This study revealed that indigenous fungal isolates of hydrocarbon-contaminated soils: Penicillium sp., Aspergillus sp. and Fusarium sp. have degradative abilities and were able to utilize hydrocarbons, thus degrading the contaminated soil in Ogbeh-Ijoh creek. They, therefore have promising potential in the bioremediation of hydrocarbon-polluted soils.

\section{Conflict of interest}

Authors declare no conflict of interest.

\section{References}

[1]. J.G. Bundy, G.I. Paton, C.D. Campbell, Combined microbial community level and single species biosensor responses to monitor recovery of oil polluted soil, Soil Biology and Biochemistry 36 (2004) 1149 - 1159.

[2]. M.F Ghazali, N.R. Zaliha, R.N. Abdul, A.B. Salleh, M. Basri, Biodegradation of hydrocarbons in soil by microbial consortium, International Biodeterioration and Biodegradation 54 (2004) 61 67.

[3]. T.G. Oteyza, J.F. Lopez, P. Teixidor, J.O. Grimalt, Long chains alkenones in hypersaline and marine coastal microbial mats, Organic Geochemistry 36 (2005) $861-872$.

[4]. X.X. Sun, J.J. Hodge, Y. Zhou, M. Nguyan, L.C. Griffith, The potassium channel binds and locally activates calcium/calmodium dependent growth kinase II, Journal of Biological Chemistry 279 (2004) 10206 - 10214.

[5]. P.V.O. Trindade, L.G. Sobral, A.C.L. Rizzo, S.G.F. Leite, A.U. Soriano, Bioremediation of a weathered and a recently oil - contaminated soil from Brazil; A comparison study, Chemosphere 58 (2004) 515 522.

[6]. S.M. Capelli, P.J. Busalmen, R.S. De Sánchez, Hydrocarbon bioremediation of a mineral-base contaminated waste from crude oil extraction by indigenous bacteria, International Biodeterioration and Biodegradation 47 (2001) 233 - 238.

[7]. J.Y. Richard, M.T. Vogel, Characterization of a soil bacterial consortium capable of degrading diesel fuel, International Biodeterioration and Biodegradation 44 (1999) 93 - 100.

[8]. S. Kim, D.H. Choi, D.S. Sim, Y. Oh, Evaluation of bioremediation effectiveness on crude oilcontaminated sand, Chemosphere 59 (2004) 845 852.

[9]. C.H. Chaineau, G. Rougeux, C. Yepremian, J. Oudot, Effect of nutrient concentration on the biodegradation of crude oil and associated microbial populations in the soil, Soil Biology and Biochemistry 37 (2005) 1490-1497.

[10]. H.S. Ferguson, D.P. Franzmann, S.I. Revill, L.J. Rayner, The effects of nitrogen and water on mineralisation of hydrocarbons in dieselcontaminated terrestrial Antarctic soils, Cold Regions Science and Technology 37 (2003) 197 212.

[11]. H. Singh, Mycoremediation: Fungal Bioremediation, p. 592, Wiley - Interscience, New York 2006.

[12]. A. Ikelegbe, The economy of conflict in the oil rich Niger Delta region of Nigeria, Journal of Third World Studies 43 (2005) 24 - 50.

[13]. C. Obi, Globalized images of environmental security in Africa, Review of African Political Economy 83 (2000) 47 - 62.

[14]. S. Fujita, Simple modified method for fungal slide preparation, Medical Mycology Journal 54 (2013) $141-146$. 
[15]. M. Brandt, D. Warnock. Taxonomy and classification of fungi. In Versalovic J., Carroll K., Funke G., Jorgensen J., Landry M., Warnock D. (ed), Manual of Clinical Microbiology, $10^{\text {th }}$ Edition, pp. 1747 - 1755, ASM Press, Washington DC 2011.

[16]. T. Mandril, J. Lin, Isolation and characterization of engine oil degrading indigenous microorganisms in KwaZulu-Natal, South Africa, African Journal Biotechnology 6 (2007) 23-27.

[17]. A.E. Ogbeibu, Biostatics: A practical approach to research and data handling, p. 264, Mindex Publishing Company Limited, Benin City 2005.

[18]. C.M.A. Iwegbue, G.E. Nwajei, F.O. Arimoro, Characteristic levels of total petroleum hydrocarbon in soil profiles of automobile mechanic waste dumps, Pakistan Journal of Scientific and Industrial Research 50 (2007) 247 - 250.

[19]. American Public Health Association (APHA) Standard Methods for the Examination of Water and Wastewater, 20 ${ }^{\text {th }}$ Edition, p. 213, APHA, Washington U.S.A. 1998.

[20]. P.O. Okerentugba, O.U. Ezeronye, Petroleum Degradation of Potentials of Single and Mixed Microbial Cultures Isolated from Rivers and Refinery Effluent in Nigeria, Africa Journal Biotechnology 2 (2003) $288-292$.

[21]. R.M. Atlas, Microbial hydrocarbon degradation: Bioremediation of oil spills, Journal of Chemical Technology Biotechnology 52 (1991) 149 - 156.

[22]. O.I. Enabulele, O.N. Obayagbona, Biodegradation potentials of mycoflora isolated from automobile workshop soils on flow station crude sludge, International Research Journal of Biological Sciences 2 (2013) 1 - 6.

[23]. O. Obire, O. Nwabueta, S.B.N. Adue, Microbial community of a waste dumpsite, Journal of Applied Science and Environmental Management 6 (2002) $78-83$.

[24]. F.O. Ekhaise, J. Nkwelle, Microbiological and Physico-chemical analyses of oil contaminated soil from major motor mechanic workshops in Benin City metropolis, Edo State, Nigeria. Journal of Applied Science and Environmental Management 15 (2011) 597 - 600.

[25]. I.A. Adeyemo, A. Sani, T.A. Aderibigbe, Growth performance and nutrient retention of broiler chickens fed Aspergillus niger hydrolysed cassava peel based diet, American Journal of Research Communication 1 (2013) 294 - 306.

[26]. S.A. Wemedo, O. Obire, D.A. Doguba, Myco-flora of a kerosene-polluted soil in Nigeria, Journal of Applied Science and Environmental Management 6 (2002) $14-77$.

[27]. B.O. Oboh, M.O. Ilori, J.O. Akinyemi, S.A. Adebusoye, Hydrocarbon-degrading potentials of Bacteria isolated from a Nigerian bitumen (Tarsand) deposit, Nature and Science 4 (2006) 51 $-57$.

[28]. G. Umanu, S.U. Nwachukwu, The use of kitchen effluent as an alternative nutrient source for bioremediation of oil-based drilling muds, Journal of Applied Science and Environmental Management 14 (2010) 5 - 11.

[29]. J.M.R. Facundo, H.R. Vanessa, M.L. Teresa, Biodegradation of diesel oil in soil by a microbial consortium, Water, Air and Soil Pollution 128 (2001) $313-320$.

[30]. G. Umanu, R.A. Owoseni, Effects of abattoir effluent on microbial degradation of diesel oil in tropical agricultural soil, Pacific Journal of Science and Technology 14 (2013) 604 - 612.

[31]. J.G. Leahy, R.R. Colwell, Microbial degradation of hydrocarbons in the environment, Microbiological Reviews 54 (1990) 305 - 315.

[32]. J.G. Bundy, G.I. Paton, C.D. Campell, Microbial communities in different soil types do not converge after diesel contamination, Journal of Applied Microbiology 92 (2002) 276 - 288.

[33]. K.S.M. Rahman, I.M. Banat, J. Thahira, Bioremediation of gasoline contaminated with poultry litter, coir pith and rhamnolipid biosurfactant, Journal of Environmental Quality 24 (2002) 19 - 28.

[34]. G. Umanu, A.R. Akpe, A.R. Omoikhudu, Oil degradation assessment of bacteria isolated from used motor oil contaminated soils in Ota, Nigeria, International Journal of Advanced Biotechnology Research 3 (2013) 506 - 513.

[35]. S.U. Nwachukwu, E.O. Ugoji, Impact of crude petroleum spills on microbial communities of tropical soils, International Journal of Ecology and Environmental Sciences 21 (1995) 169 - 176.

[36]. G.C. Okpokwasili, W.A. James, Microbial contamination of kerosene, gasoline and crude oil and their spoilage potentials, Material und Organismen 29 (1995) 147 - 156.

[37]. S. Boonchan, M.L. Britz, G.A. Stanley, Degradation and mineralisation of high-molecular weight polycyclic aromatic hydrocarbons by defined fugal-bacterial co-cultures, Applied Environmental Microbiology 66 (2000) 1007 1019.

[38]. S.B. Akinde, O. Obire, Aerobic heterotrophic bacteria and petroleum-utilising bacteria from cow dung and poultry manure, World Journal of Microbiology and Biotechnology 24 (2008) 1999 2002.

[39]. R.O. Anyasi, H.I. Atagana, Biological remediation of polychlorinated biphenyls (PCB) in the environment by microorganisms and plants, African Journal of Biotechnology 10 (2011) 18916 $-18938$.

[40]. U. George-Okafor, F. Tasie, F. Muotoe-Okafor, Hydrocarbon degrading potentials of indigenous fungal isolates from petroleum contaminated soils, Journal of Physical and Natural Sciences 3 (2009) 1 -6 .

Received: 21.06 .2018

Received in revised form: 28.07.2018

Accepted:03.08.2018 